\title{
Culturability and Viability of Salmonella Typhimurium during Photo-Fenton Process at pH 5.5 under Solar Simulated Irradiation
}

\author{
Julián A. Rengifo-Herrera ${ }^{1^{*}}$, Olga L. Castaño ${ }^{2}$, Irma J. Sanabria ${ }^{2^{*}}$ \\ ${ }^{1}$ Center of Research and Development in Applied Sciences, "Dr. J. J. Ronco" (CINDECA), Chemistry Department, \\ Faculty of Exact Sciences, UNLP-CCT La Plata, Buenos Aires, Argentina \\ ${ }^{2}$ Research Group in Oxidation Advanced Processes for Chemical and Biological Treatments (GAOX), \\ University del Valle, Cali, Colombia. \\ Email: ${ }^{*}$ julianregifo@quimica.unlp.edu.ar, ${ }^{*}$ sanabria@correounivalle.edu.co
}

Received May 31, 2013; revised July 5, 2013; accepted August 3, 2013

Copyright (C) 2013 Julián A. Rengifo-Herrera et al. This is an open access article distributed under the Creative Commons Attribution License, which permits unrestricted use, distribution, and reproduction in any medium, provided the original work is properly cited.

\begin{abstract}
Culturability and viability techniques such as plate count on solid agar (PC), Most Probable Number (MPN) and Direct Viable Count-Fluorescence in Situ Hybridation (DVC FISH) were used to study the inactivation of Salmonella typhimurium by photo-Fenton process at $\mathrm{pH}$ 5.5. In the presence of only simulated solar irradiation $\left(500 \mathrm{~W} \cdot \mathrm{m}^{-2}\right), S$. typhimurim showed that both culturability measured by MPN and viability (measured by DVC FISH) underwent just a slight decreasing of 2 and $1 \log$ respectively after $240 \mathrm{~min}$ of light exposition while culturability measured by PC did not show any change. Results after $48 \mathrm{~h}$ of dark conditions did not reveal re-growth. However, when experiment was carried out in the presence of $2 \mathrm{mg} \cdot \mathrm{L}^{-1}$ of $\mathrm{Fe}^{3+}$ and $20 \mathrm{mg} \cdot \mathrm{L}^{-1}$ of $\mathrm{H}_{2} \mathrm{O}_{2}$ and $\mathrm{pH} 5.5$, culturability was strongly affected after $240 \mathrm{~min}$ of simulated solar irradiation; nevertheless, viability was only slightly altered $(\sim 1 \mathrm{log})$. During dark period of $48 \mathrm{~h}$ changes on culturability and viability were not observed. On the other hand, it was also found that sugar metabolism was affected rather the amino-acids in $S$. typhimurium cells irradiated at different times upon photo-Fenton conditions. These findings might suggest for the first time that photo-Fenton process at $\mathrm{pH} 5.5$ could induce viable but nonculturable state (VBNC) on waterborne $S$. typhimurium and that probably sugar metabolism damage could activate the VBNC state.
\end{abstract}

Keywords: Photo-Fenton Disinfection; Salmonella Typhimurium Inactivation; VBNC State; Viability and Cultivability

\section{Introduction}

Photo-Fenton processes which are based in the light induced reaction of ferrous and/or ferric ions with hydrogen peroxide to generate reactive oxygen species such as protonated superoxide $\left(\mathrm{HO}_{2} \bullet\right)$ and $\bullet \mathrm{OH}$ radical, have recently risen as a promising method to inactivate waterborne bacteria [1-5].

$$
\begin{gathered}
\mathrm{Fe}^{2+}+\mathrm{H}_{2} \mathrm{O}_{2} \rightarrow \mathrm{Fe}^{3+}+\mathrm{HO}^{-}+\cdot \mathrm{OH} \\
\mathrm{Fe}^{3+}+\mathrm{H}_{2} \mathrm{O}_{2} \rightarrow \mathrm{Fe}^{2+}+\mathrm{HO}_{2} \cdot+\mathrm{H}^{+} \\
\mathrm{Fe}(\mathrm{OH})^{2+}+\mathrm{hv} \rightarrow \mathrm{Fe}^{2+}+\bullet \mathrm{OH}+\mathrm{H}^{+}
\end{gathered}
$$

Recent studies reported that solar photo-Fenton process at near neutral $\mathrm{pH}(5.5)$ achieved a complete inactiva-

${ }^{*}$ Corresponding authors. tion of wild Salmonella sp., a pathogen bacterial strain resistant to solar disinfection [6], without re-growth after $72 \mathrm{~h}$ of dark storage by simple addition of $\mathrm{H}_{2} \mathrm{O}_{2}$ in natural waters containing iron at neutral $\mathrm{pH}$ [7]. Furthermore at $\mathrm{pH} 5.5$ it was demonstrated that ferric ions undergo a strong interaction with $E$. coli cells avoiding its precipitation and inactivating efficiently the bacteria cells [4]. However all disinfection studies performed with photoFenton processes either at acid or near neutral $\mathrm{pH}$ have been carried out using plate count methods on solid agar to quantify the microorganisms $[2,4,5,7,8]$; this procedure could give a false positive since it takes only into account the cell culturability neglecting its viability. Several studies have suggested that when bacteria undergo oxidative stress by the presence of UV light or toxic substances such as radicals, they could enter in the 
transient viable but nonculturable state (VBNC), produced by oxidative stress; VBNC state is a condition where microorganisms lose its capacity to grow in nutritive media $[9,10]$. Nevertheless, when the oxidative stress ceases, microbial cells can undergo resuscitation where they recover their culturability under specific conditions [10]. This later fact is a key point since some authors have suggested Salmonella typhimurium cells could maintain their virulence during VBNC state, and this could imply a serious threat to human health in disinfection processes [11-13].

There are methodologies that can determinate the cell viability. Among them the coupling of Direct Viable count (DVC) with Fluorescence in situ Hybridation (FISH) seems to be effective to determinate viability of waterborne bacterial cells [14]. Moreover the coupling of DVC with FISH has successfully been used to determinate viability in Escherichia coli cells from natural waters and seems to be a powerful technique to evaluate the viability of waterborne enteric bacteria $[15,16]$.

Herein, for the first time, culturability and viability were measured simultaneously by PC, MPN and DVCFISH of S. typhimurim being exposed to the photo-Fenton processes induced by simulated solar light irradiation at $\mathrm{pH}$ 5.5. It is suggested that this photochemical process could induce on the bacterial cells VBNC state avoiding their growing on solid agar and liquid media after 240 min of simulated solar irradiation. This fact is extremely important since it might allow evaluate precisely the ability and limitations of photo-Fenton process to inactive pathogen waterborne bacteria.

\section{Materials and Methods}

\subsection{Photochemical and Photo-Fenton Experiments at $\mathbf{p H} 5.5$}

Pyrex glass bottles of $80 \mathrm{~mL}(3.5 \mathrm{~cm}$ in diameter and 10 $\mathrm{cm}$ high) were used as batch reactors. $2 \mathrm{mg} \cdot \mathrm{L}^{-1}$ of $\mathrm{Fe}^{3+}$ ( $\mathrm{FeSO}_{4} \cdot 7 \mathrm{H}_{2} \mathrm{O}$ (Merck-Germany)) and $20 \mathrm{mg} \cdot \mathrm{L}^{-1}$ of $\mathrm{H}_{2} \mathrm{O}_{2}$ (Merck-Germany 30\% (v/v)) were added to $80 \mathrm{~mL}$ of an isotonic solution containing distilled water and $\mathrm{NaCl}$ (Sigma-Aldrich Germany) $\left(8.0 \mathrm{~g} \cdot \mathrm{L}^{-1}\right), \mathrm{KCl}$ (Merck Germany) $\left(0.8 \mathrm{~g} \cdot \mathrm{L}^{-1}\right)$ in each reactor. The initial $\mathrm{pH}$ was adjusted by $\mathrm{NaOH}$ (Merck Germany) addition until reaching 5.5, not buffer was used. Solar irradiation was simulated by a Hanau Suntest solar simulator (Germany) having a wavelength spectral distribution with about $0.5 \%$ of emitted photons $<300 \mathrm{~nm}$ (UV-C range) and about $7 \%$ between 300 and $400 \mathrm{~nm}$ (UV-B, A range). The emission spectrum between 400 and $800 \mathrm{~nm}$ follows the solar spectrum (Figure 1). Light intensity in all experiments was $500 \mathrm{~W} \cdot \mathrm{m}^{-2}$ and it was monitored with a Kipp \& Zonen (CM3) power meter (Omni instruments,

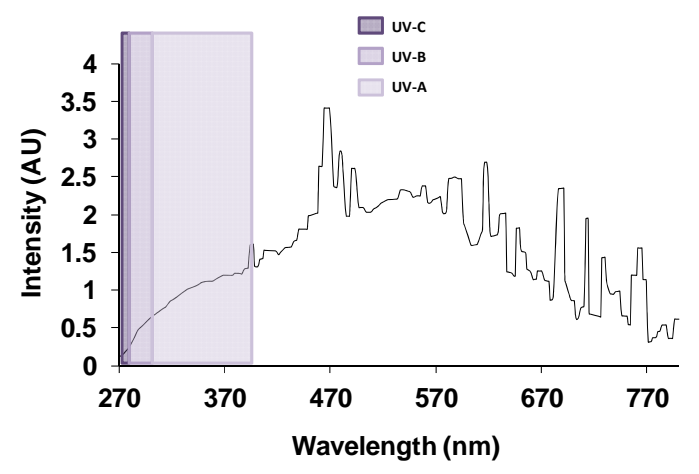

Figure 1. Emission spectrum of solar simulator Hannau Suntest.

Dundee, UK). Pyrex bottles containing inoculated S. typhimurium were illuminated in the presence and absence of $\mathrm{Fe}^{3+}$ and $\mathrm{H}_{2} \mathrm{O}_{2}$ during $4 \mathrm{~h}$ and samples $(1.0 \mathrm{~mL})$ were taken at different time intervals and serial dilutions were performed in saline solution.

The irradiation experiments were performed at room temperature $\left(25^{\circ} \mathrm{C}\right)$ and the temperature of the solution increased up to approximately $30^{\circ} \mathrm{C}$ during irradiation. All experiments were carried out in equilibrium agitating at $700 \mathrm{rpm}$ in triplicate and the error bars were added on the graphs.

\subsection{Preparation of Salmonella Typhimurium Strain}

A strain of S. typhimurium ATCC 15490 (Washington DC, USA) was used during these experiments. Strain was preserved in a $30 \%$ glycerol solution to avoid membrane rupture during freezing storage. The bacterial reactivation was achieved by inoculating $10 \mathrm{~mL}$ of nutrient broth (Oxoid) with $100 \mu \mathrm{L}$ of bacterial suspension, and then incubating for $18 \mathrm{~h}$ at $35^{\circ} \mathrm{C}$. A second inoculum was transferred from this culture to a new tube with $10 \mathrm{~mL}$ of nutrient broth and again incubated for $18 \mathrm{~h}$ at $35^{\circ} \mathrm{C}$. This second culture was washed by centrifuging at $3000 \mathrm{rpm}$ for $10 \mathrm{~min}$; the supernatant was carefully extracted so the pellet can be suspended and diluted in $10 \mathrm{~mL}$ of $0.1 \%$ peptonized bi-distillated water (Milli-Q water), agitated and centrifuged again. This procedure was repeated three times, leaving the last cell pellet suspended in $10 \mathrm{~mL}$ of $0.1 \%$ peptonized bi-distillated water. The final concentration of the washed cell suspension was adjusted according to the McFarland scale \#0.5 at $1.5 \times 10^{8} \mathrm{CFU}$ $\mathrm{m} \cdot \mathrm{L}^{-1}$. Consecutive dilutions $\left(10^{-1}-10^{-4}\right)$ of the adjusted cell suspension $\left(1.5 \times 10^{8} \mathrm{CFU} \mathrm{m} \cdot \mathrm{L}^{-1}\right)$ were made in tubes with $9 \mathrm{~mL}$ of $0.1 \%$ peptonized water (Oxoid), and seeded onto nutrient agar to be incubated for $18 \mathrm{~h}$ at $35^{\circ} \mathrm{C}$ to establish the initial concentration. This cell suspension was used to inoculate the batch reactors containing the isotonic saline distillated water with $\mathrm{Fe}^{3+}\left(\mathrm{FeSO}_{4} \cdot 7 \mathrm{H}_{2} \mathrm{O}\right.$ (Merck-Germany)), and $\mathrm{H}_{2} \mathrm{O}_{2}$ (Merck-Germany), to initi- 
ate irradiation experiments.

\subsection{Culturability Measurement of Salmonella Typhimurium by MPN and PC}

\subsubsection{PC Method}

$100 \mu \mathrm{L}$ from each dilution were seeded onto Petri dishes containing Nutrient Agar (Merck-Germany) and incubated at $37^{\circ} \mathrm{C} \pm 2{ }^{\circ} \mathrm{C}$ for $24 \mathrm{~h}$ to obtain the CFU measuring.

\subsubsection{MPN Method}

$1 \mathrm{~mL}$ from each dilution were inoculated onto tubes with $9 \mathrm{~mL}$ of lactose broth (Difco) and incubated at $35^{\circ} \mathrm{C} \pm$ $2^{\circ} \mathrm{C}$ for $24 \mathrm{~h}$ in order to initiate the presumptive phase. The positives for bacterial growth were then recovered in Rappaport broth (Merck-Germany) before being seeded on Hektoen (Merck-Germany), Xylose, Lysine Desoxycholate agar (XLD agar) (Difco-France) and Nutrient agar (Merck-Germany) to finalize with the confirmatory phase.

\subsection{Viability Measurement of Salmonella Typhimurium by DVC FISH}

The FISH-DAPI coloration procedure suggested by Amman et al. [17] was used for the total cell enumeration, while viable cells were enumerated using the DVCFISH method proposed by Kogure et al. [18] and Regnault et al. [19] with the following modifications.

\subsubsection{DVC-FISH}

The remaining $8.8 \mathrm{~mL}$ sample in each dilution tube were treated with Nalidixic acid $\left(40 \mu \mathrm{g} \mathrm{mL}^{-1}\right)$ and $1 \mathrm{~mL}$ of lactose broth (Difco-France) and yeast extract (DifcoFrance), then incubated in the dark for $18 \mathrm{~h}$ at $35 \pm 2{ }^{\circ} \mathrm{C}$. Cells were harvested by centrifugation at $5000 \mathrm{~g}$. Depending on the expected concentration, 100 or $300 \mu \mathrm{L}$ were re-suspended in $10 \mathrm{x}$ phosphate buffered saline (PBS) solution to reach $1 \mathrm{~mL}$ and fixated with a paraformaldehyde fixation buffer $30 \%(\mathrm{v} / \mathrm{v})$, stored overnight at $4^{\circ} \mathrm{C}$, and harvested by centrifugation at $1000 \mathrm{~g}$ for 10 min. The pellets were washed with PBS solution. This washing process was repeated two times to ensure the complete removal of $p$-formaldehyde, and the final pellets were re-suspended in $500 \mu \mathrm{L}$ of $1 \times$ PBS and $500 \mu \mathrm{L}$ of ethanol $100 \%$. $10 \mu \mathrm{L}$ of the resulting cell suspension was transferred to each well of a 8-well slide, previously covered with gelatine $(0.1 \% \mathrm{w} / \mathrm{v})$ and $\mathrm{KCr}\left(\mathrm{SO}_{4}\right)_{2}$ (MerckGermany) $(0.01 \% \mathrm{w} / \mathrm{v})$. The loaded slides were dehydrated with ethanol and incubated for $2 \mathrm{~h}$ in the dark with $10 \mu \mathrm{L}$ of hybridization solution pre-warmed at $45^{\circ} \mathrm{C}$ and containing $24 \mathrm{ng} \cdot \mu \mathrm{L}^{-1}$ of $S$. typhimurium probe $[16,20]$, marked with 5' Cy3 (prepared by Microsynth GmbH Switzerland). Finally, cells were washed with a washing solution at $45^{\circ} \mathrm{C}$ and then rinsed with distilled water.

\subsubsection{DAPI}

After hybridization, all samples were washed in distilled water and stained with $9 \mu \mathrm{L}$ of DAPI (Organic Research-Ireland) (4',6'-diamidino-2-phenylindole) $0.0001 \%$ $(\mathrm{w} / \mathrm{v})$ for 10 minutes, washed again in distilled water and dried (to aid cell localization, slides were cover with antifade citi-fluor solution). Microscopic cell count (DAPI) and oligonucleotide probe-positive count (Cy3) were performed using a Nikon Eclipse E800 microscope (Japan) equipped with a specific DAPI filter and G-2A filter sets. A minimum of 20 view squares were enumerated for each well; two wells were examined in total.

\subsection{Assays of Growing in Mineral Enriched Media}

Four tubes containing $20 \mathrm{~mL}$ of mineral media containing distilled water and $\mathrm{NaCl}$ (Sigma-Aldrich Germany) $\left(8.0 \mathrm{~g} \cdot \mathrm{L}^{-1}\right), \mathrm{KCl}$ (Merck Germany) $\left(0.8 \mathrm{~g} \cdot \mathrm{L}^{-1}\right)$ and $20 \%$ of Glucose (Merck Germany) or Peptone (DIFCO UK), respectively, were inoculated with $1 \mathrm{~mL}$ of irradiated bacteria. The turbidity at $650 \mathrm{~nm}$ was measured after 18 , 24 , and $96 \mathrm{~h}$ of incubation and the increase in 0.1 or more turbidity units was reported as positive growth.

\section{Results and Discussion}

\subsection{Effect of Simulated Solar Light Arradiation on Culturability and Viability of $S$. Typhimurium Cells in Absence of Ferric Ions and $\mathrm{H}_{2} \mathrm{O}_{2}$}

The initial $S$. typhimurium concentration before irradiation events, evaluated with DVC FISH and MPN methods, achieved concentrations two logs higher than the PC method (Figure 2). Although there is no difference between the nutrient composition of a liquid and a solid culture media, in practice the culture broths have a higher

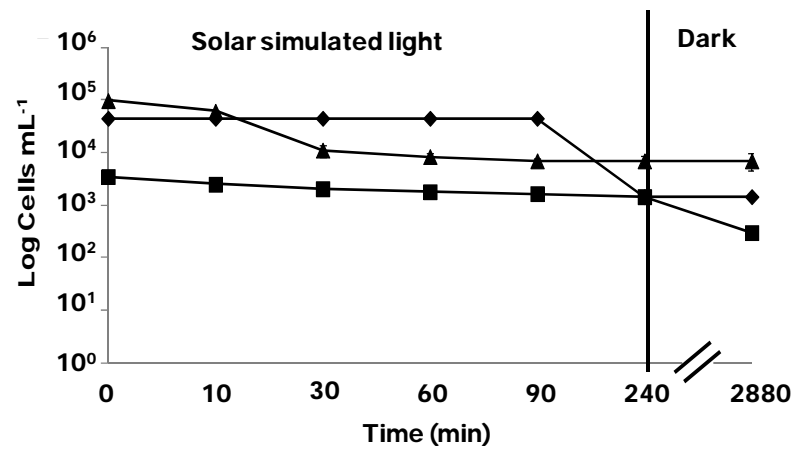

Figure 2. Inactivation of $S$. typhimurium by simulated solar light $\left(500 \mathrm{~W} \cdot \mathrm{m}^{-2}\right)$ at $\mathbf{p H} 5.5$ followed by $-m-\mathrm{PC},->-\mathrm{MPN}$ and - $\triangle$-DVC FISH. 
rate of cell recovery. In solid media (PC method) the bacteria growing is limited by the availability of water and nutrients close to the colony's growing area while the liquid media (MPN and Nalidixic media) ensures constant and direct contact of cell with nutrients. This could explain why DVC-FISH and MPN gave initial concentrations higher than PC.

On the other hand, results obtained by MPN and PC (Figure 2) revealed that after $240 \mathrm{~min}$ of solar simulated irradiation, the former method showed that Salmonella population underwent a decreasing of almost 2 logs while the later did not show any decreasing of bacterial concentration. Furthermore, DVC FISH viability count underwent a slight decreasing of its initial concentration $(\sim 1 \mathrm{log})$ after of $240 \mathrm{~min}$ of solar simulated irradiation. The experiments were followed by $48 \mathrm{~h}$ in dark conditions and the results showed that DVC FISH and MPN did not undergo neither decreasing nor re-growth on the bacterial population. However PC method showed a slight decreasing of almost $1 \log$ probably due to the fact that under these conditions weakened microorganisms (by UV irradiation) could undergo an additional stress by the lack of nutrients. This decreasing of $E$. coli population after a photocatalytic treatment (in presence of $\mathrm{TiO}_{2}$ and solar simulated light) under dark conditions was already observed by Rincon and Pulgarin [21] and referred as post-irradiation events.

In summary, the three methods used in this study (DVC FISH, MPN and PC) revealed that direct solar simulated irradiation had slight negative effect on the $S$. typhimurium population. It is well known that UV-C component $(220-280 \mathrm{~nm})$ of UV light is the most lethal to the microorganisms since it might produce chemical changes on the DNA components [22]. Solar simulator emits few UV-C light irradiation (Figure 1) and this fact could explain why light irradiation did not affect in a larger extent of the initial concentration of S. typhimurium. However, the UV-A (320 - $400 \mathrm{~nm})$ is emitted by the solar simulator and some studies have argued that this UV component could affect the activity of antioxidant enzymes such as superoxide dismutase (SOD), catalase, and could also produce partial degradation of iron-containing proteins, releasing $\mathrm{Fe}$ (II) ions into the cell [23, 24]. Thus, only the presence of UV-A light could generate a bacteria weakening by diminishing its antioxidant capacity without producing a lethal damage.

\subsection{Effect of Photo-Fenton Process at near Neutral pH on Culturability and Viability of S. typhimurium Cells}

Figure 3 shows that culturability measured by MPN and PC was strongly affected by photo-Fenton process at $\mathrm{pH}$ 5.5. Results obtained by MPN revealed a diminution of 4 logs after 240 min of simulated solar irradiation and PC

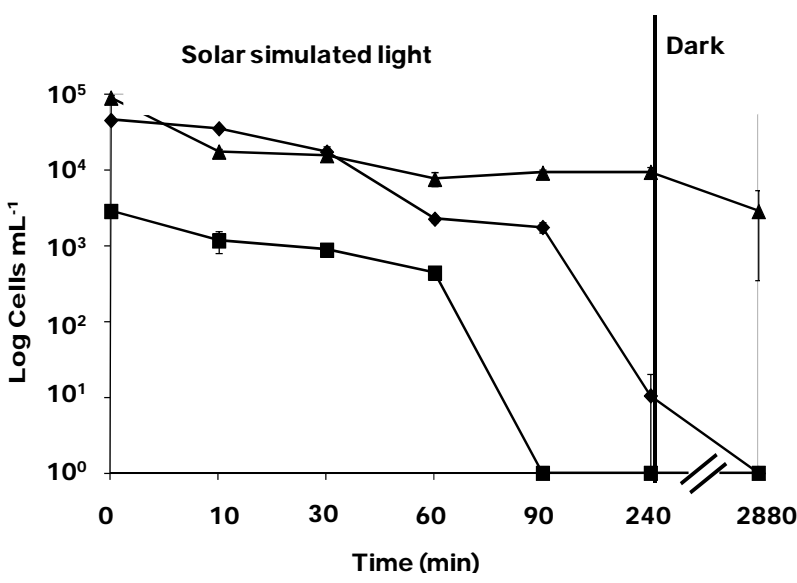

Figure 3. Inactivation of $S$. typhimurium by simulated solar light $\left(500 \mathrm{~W} \cdot \mathrm{m}^{-2}\right)$ in presence of $\left.2 \mathrm{mg} \cdot \mathrm{L}^{-1}\right)$ of $\mathrm{Fe}^{3+}$ and 20 $\mathrm{mg} \cdot \mathrm{L}^{-1}$ of $\mathrm{H}_{2} \mathrm{O}_{2}$ at $\mathrm{pH} 5.5$ followed by $-\square-\mathrm{PC},--\mathrm{MPN}$ and - $A$-DVC FISH.

results showed a total loss of culturability after $90 \mathrm{~min}$ of irradiation. In contrast, viability followed by DVC FISH underwent a slight decreasing of around 1 log. In dark conditions no re-growth or loss of viability was observed.

A previous study [4] revealed that neither $\mathrm{H}_{2} \mathrm{O}_{2}$ nor ferric ions induced a strong toxic effect on $E$. coli cells and in this study was found the same trends (Data not shown).

Photo-Fenton processes are often carried out at acidic $\mathrm{pH}$ in order to avoid iron precipitation. However, in aqueous media and at $\mathrm{pH}$ close to 5 , iron soluble species such as $\mathrm{Fe}(\mathrm{OH})_{2}{ }^{+}$exist and could lead to the formation of high oxidative radicals [3,25]. Furthermore, a recent study reported that ferric ions at $\mathrm{pH} 5.5$ are strongly adsorbed by E. coli cells preventing its precipitation [4]. Although several studies have reported photo-Fenton process as a promising technology to inactivate waterborne bacteria $[2,4,5,7,8]$, these have only followed culturability on solid media. Until now, there are not studies regarding bacterial viability during and after the photoFenton process.

When bacteria cells among them $S$. typhimurium undergo oxidative stress caused by the presence of external or internal toxic substances or by the presence of oxidative radicals, they can enter in a state called VBNC that seems to be an adaptive response aimed to survive in adverse conditions $[10,26]$, where the metabolic processes decrease avoiding that bacteria can grow on solid or liquid media. This fact could explain why during photo-Fenton process, S. typhimurium cells showed a strong loss of culturability while viability remains almost unaltered. Recently, it was suggested that iron cations could interact strongly with negatively charged $E$. coli membranes [4] (isoelectric point $\sim 4.3$ [27]) at near neutral $\mathrm{pH}$. Once the photo-Fenton process at $\mathrm{pH} 5.5$ (with iron cations and $\mathrm{H}_{2} \mathrm{O}_{2}$ on the outer membrane) induces 
the formation of $\bullet \mathrm{OH}$ with a higher oxidative power $(2.8$ $\mathrm{eV}$ vs NHE) but shorter lifetime (ns); these radicals might attack only the $S$. typhimurium outer membrane inducing lipid peroxidation (LPO) and causing permeability alterations [28]. Furthermore, it has been reported that $\mathrm{H}_{2} \mathrm{O}_{2}$ might also induce changes on motility and catalase activity in $S$. typhimurium affecting its ability to defend against the deleterious reactions of reactive oxygen species (ROS) or oxidative attack [29]. Moreover, some studies have reported that in bacteria such as Vibrio vulnificus and $E$. coli $0157: H$ the decreasing of catalase activity and the presence of $\mathrm{H}_{2} \mathrm{O}_{2}$ would be narrowly linked to the VBNC state induction [30,31].

In order to evaluate the recovery of $S$. typhimurium after different exposure times during the photo-Fenton treatment, irradiated cells where transferred onto two different solutions of mineral media enriched with either glucose or peptone, measuring optical density (O.D.) after 18, 24 and $96 \mathrm{~h}$ of dark storage (Table 1). Results show that $S$. typhimurium grows in both media before photochemical treatment since cells have not undergone any damage. This agrees with previous studies [32].

After $1 \mathrm{~h}$ of photo-Fenton treatment and $18 \mathrm{~h}$ in dark storage, $S$. typhimurium cells did not show any growth in glucose-enriched media, but then at $24 \mathrm{~h}$ and $96 \mathrm{~h}$ in dark storage re-growth was observed. With $2 \mathrm{~h}$ and $3 \mathrm{~h}$ of photo-Fenton treatment, bacterial re-growth was observed only at $96 \mathrm{~h}$ in dark storage. Finally after $4 \mathrm{~h}$ of photochemical treatment $S$. typhimurium did not show any re-growth at $18 \mathrm{~h}, 24 \mathrm{~h}$ or $96 \mathrm{~h}$ in dark storage.

When using peptone-enriched mineral media for cell recovery, different results were obtained. Bacterial cells grew after 1, 2 and $3 \mathrm{~h}$ of photo-Fenton treatment during 18 and $24 \mathrm{~h}$ in dark storage. However after $4 \mathrm{~h}$ of photochemical treatment media did not showed any growth. These results imply that photo-Fenton treatment might induce damages on sugar metabolism rather than aminoacidic metabolism (peptone is conformed mainly by aminoacids) in S. typhimurium cells.

Herein is suggested that the UV-A irradiation and

Table 1. Cell grow ability under mineral media enriched either glucose or peptone monitored after photo-Fenton treatment during dark storage.

\begin{tabular}{ccccccc}
\hline $\begin{array}{c}\text { Irradiation } \\
\text { time }(\mathrm{h})\end{array}$ & \multicolumn{3}{c}{ Glucose } & \multicolumn{5}{c}{ Peptone } \\
\hline & 18 & 24 & 96 & 18 & 24 & 96 \\
& + & + & + & + & + & + \\
0 & - & - & + & + & + & + \\
1 & - & - & + & + & + & + \\
2 & - & - & + & + & + & + \\
3 & - & - & - & - & - & - \\
\hline
\end{tabular}

$\mathrm{H}_{2} \mathrm{O}_{2}$ might affect the catalase activity of $S$. typhimurium, weakening its anti-oxidant capacity. Furthermore, the attack of $\cdot \mathrm{OH}$ radicals might produce damages mainly on the outer membrane by lipid peroxidation (LPO) or oxidizing proteins responsible of sugar metabolism (SMP). This could be the trigger alarm inside the microorganism to make it enter into the VBNC state (Figure 4). Probably, S. typhimurium cells in VBNC state could maintain its infective capacity after $4 \mathrm{~h}$ of near neutral photoFenton treatment under solar simulated irradiation. This fact should represent a high risk for human health, since non-culturable cells of pathogenic bacteria can retain substantial physiological activity, including the capacity to synthesize toxins being able to induce disease [30,33].

In spite of these results, further experiments are necessary in order to find the experimental conditions where photo-Fenton processes can reach viability loss and grant the bacterial dead. Furthermore, studies of molecular biology must be carried out to understand what cell targets are attacked during the photo-Fenton process.

\section{Conclusions}

Culturability and viability of $S$. typhimurium cells during photo-Fenton process at $\mathrm{pH} 5.5$ induced by solar simulator light was followed through culturability and viability techniques such as PC, MPN and DVC FISH.

Results showed that under our experimental conditions photo-Fenton process strongly affects the $S$. typhimurium cells culturability rather its viability. Thus, this photochemical process might induce a VBNC state probably due to a combined effect of UV-A light, $\mathrm{H}_{2} \mathrm{O}_{2}$ induced-weakening of catalase activity, and the oxidative attack of photo-induced $\cdot \mathrm{OH}$ radicals on the outer bacterial membrane causing lipid peroxidation and loss of permeability. Besides, it was found that glucose metabolism rather the amino acid was affected by photo-Fenton processes at near neutral $\mathrm{pH}$.

The presence of S. Typhimurium in VBNC state after near neutral photo-Fenton process induced by solar light might be a serious issue since this would demonstrate that this photo-Fenton process might cause a bacterio-

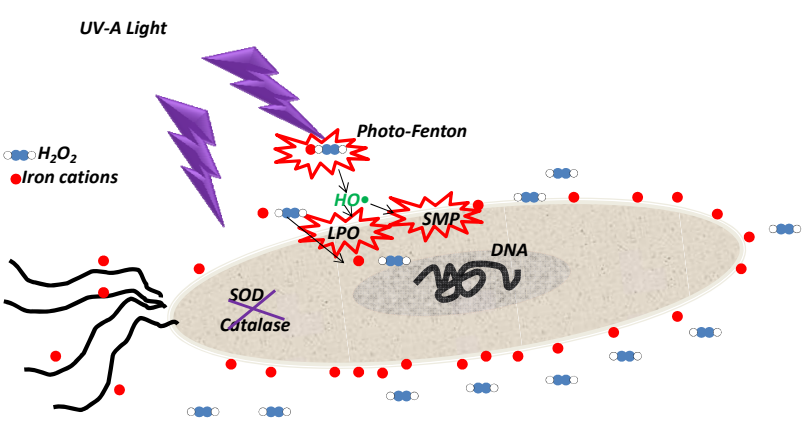

Figure 4. Suggested mechanism of VBNC state induced by photo-Fenton at $\mathrm{pH} 5.5$ on $S$. typhimurium cells. 
static but not a bactericidal effect. However in spite of these results, further experiments are necessary to under-stand the true effect of photo-Fenton processes on wa-terborne bacteria inactivation and find the experimental conditions where viability is also affected since thus the possibility of re-growing after photo-Fenton processes would be reduced.

\section{Acknowledgements}

Authors gratefully thank to MincyT (Argentina) and COLCIENCIAS (Colombia) for their support to the project ECOS-NORD (CO/10/04). The authors thank specially to Sandra Rivera for her collaboration in the laboratory.

\section{REFERENCES}

[1] J. J. Pignatello, E. Oliveros and A. MacKay, "Advanced Oxidation Processes for Organic Contaminant Destruction Based on the Fenton Reaction and Related Chemistry," Critical Reviews in Environmental Science and Technology, Vol. 36, No. 1, 2006, pp. 1-84. doi:10.1080/10643380500326564

[2] A. G. Rincon and C. Pulgarin, "Comparative Evaluation of $\mathrm{Fe}^{3+}$ and $\mathrm{TiO}_{2}$ Photoassisted Processes in Solar Photocatalytic Disinfection of Water," Applied Catalysis B: Environmental, Vol. 63, No. 3-4, 2006, pp. 222-231. doi:10.1016/j.apcatb.2005.10.009

[3] S. Malato, P. Fernández-Ibañez, M. I. Maldonado, J. Blanco and W. Gernjak, "Decontamination and Disinfection of Water by Solar Photocatalysis: Recent Overview and Trends," Catalysis Today, Vol. 147, No. 1, 2009, pp. 1-59. doi:10.1016/i.cattod.2009.06.018

[4] D. Spuhler, J. A. Rengifo-Herrera and C. Pulgarin, "The Effect of $\mathrm{Fe}^{2+}, \mathrm{Fe}^{3+}, \mathrm{H}_{2} \mathrm{O}_{2}$ and the Photo-Fenton Reagent at near Neutral $\mathrm{pH}$ on the Solar Disinfection (SODIS) at Low Temperatures of Water Containing Escherichia coli K-12," Applied Catalysis B: Environmental, Vol. 96, No. 1-2, 2010, pp. 126-141. doi:10.1016/j.apcatb.2010.02.010

[5] I. García-Fernández, M. I. Polo-López, I. Oller and P. Fernández-Ibáñez, "Bacteria and Fungi Inactivation Using $\mathrm{Fe}^{3+} /$ Sunlight, $\mathrm{H}_{2} \mathrm{O}_{2}$ /Sunlight and near Neutral Photo-Fenton: A Comparative Study," Applied Catalysis B: Environmental, Vol. 121-122, 2012, pp. 20-29. doi:10.1016/j.apcatb.2012.03.012

[6] M. Berney, H.-U. Weilenmann, A. Simonetti and T. Egli, "Efficacy of Solar Disinfection of Escherichia coli, Shigella flexneri, Salmonella typhimurium and Vibrio cholera," Journal of Applied Microbiology, Vol. 101, No. 4, 2006, pp. 828-836.

doi:10.1111/j.1365-2672.2006.02983.x

[7] F. Sciacca, J. A. Rengifo-Herrera, J. Wéthé and C. Pulgarin, "Dramatic Enhancement of Solar Disinfection (SODIS) of Wild Salmonella sp. in PET Bottles by $\mathrm{H}_{2} \mathrm{O}_{2}$ Addition on Natural Water of Burkina Faso Containing Dissolved Iron," Chemosphere, Vol. 78, No. 9, 2010, pp. 11861191. doi:10.1016/j.chemosphere.2009.12.001
[8] A. Moncayo-Lasso, L. E. Mora-Arizmendi, J. A. RengifoHerrera, J. Sanabria, N. Benitez and C. Pulgarin, "The Detrimental Influence of Bacteria (E. coli, Shigella and Salmonella) on the Degradation of Organic Compounds (and Vice-Versa) in $\mathrm{TiO}_{2}$ Photocatalysis and near Neutral Photo-Fenton Processes under Simulated Solar Light," Photochemical \& Photobiological Sciences, Vol. 11, No. 5, 2012, pp. 821-827. doi:10.1039/c2pp05290c

[9] D. B. Roszak and R. R. Colwell, "Survival Strategies of Bacteria in the Natural Environment," Microbiological Reviews, Vol. 51, No. 3, 1987, pp. 365-379.

[10] G. V. Mukamolova, A. S. Kaprylants, D. B. Kell and M. Young, "Adoption of the Transiently Non-Culturable State: A Bacterial Survival Strategy?" Advances in Microbial Physiology, Vol. 47, 2003, pp. 65-129. doi:10.1016/S0065-2911(03)47002-1

[11] A. P. Caro, J. Got, S. Lesne, A. Binard and B. Baleux, "Viability and Virulence of Experimentally Stressed Nonculturable Salmonella typhimurium," Applied and Environmental Microbiology, Vol. 65, No. 7, 1999, pp. 32293232.

[12] J. S. Lesne, S. Berthet, A. Binard, J. Rouxel and F. Humbert, "Changes of Culturability and Virulence of Salmonella typhimurium during Long-Term Starvation under Dessicating Conditions," International Journal of Food Microbiology, Vol. 60, No. 2-3, 2000, pp. 195-203. doi:10.1016/S0168-1605(00)00311-1

[13] L. A. Bjergbaek and P. Roslev, "Formation of Nonculturable Escherichia coli in Drinking Waters," Journal of Applied Microbiology, Vol. 99, No. 5, 2005, pp. 10901098. doi:10.1111/j.1365-2672.2005.02706.x

[14] C. Almeida, N. F. Azevedo, R. M. Fernandez, C. W. Keewil and M. J. Vieira, "Fluorescent in Situ Hybridization Method Using a Peptide Nucleic Acid Probe for Identification of Salmonella spp. in a Broad Spectrum Samples," Applied and Environmental Microbiology, Vol. 76, No. 13, 2010, pp. 4476-4485. doi:10.1128/AEM.01678-09

[15] T. García-Armisen and P. Servais, "Enumeration of Viable E. coli in Rivers and Wastewaters by Fluorescent in situ Hybridization," Journal of Microbiological Methods, Vol. 58, No. 2, 2004, pp. 269-279. doi:10.1016/j.mimet.2004.04.014

[16] S. P. Rivera, L. Flores and J. Sanabria, "Standardization of a Quantification Method for Salmonella spp. and Shigella spp. in Specific Liquid Media," Colombia Médica, Vol. 41, No. 1, 2010, pp. 60-70.

[17] R. I. Amann, L. Krumholz and D. A. Stahl, "FluorescentOligonucleotide Probing of Whole Cells for Determinative, Phylogenetic, and Environmental Studies in Microbiology," Journal of Bacteriology, Vol. 172, No. 2, 1990, pp. 762-770.

[18] K. Kogure, U. Simidu and N. A. Taga, "A Tentative Direct Microscopic Method for Counting Living Marine Bacteria," Canadian Journal of Microbiology, Vol. 25, No. 3, 1979, pp. 415-420.

[19] Regnault, S. Martin-Delautre and P. Grimont, "Problems Associated with the Direct Viable Count Procedure Applied to Gram-Positive Bacteria," International Journal of 
Food Microbiology, Vol. 55, No. 1, 2000, pp. 281-284. doi:10.1016/S0168-1605(00)00204-X

[20] S. Norsdentoft, H. Christensen and H. C. Wegener, "Evaluation of a Fluorescence Labelled Oligonucleotide Probe Targeting 23S rRNA for in Situ Detection of Salmonella serovars in Paraffin-Embedded Tissue Sections and Their Rapid Identification in Bacterial Smears," Journal of Clinical Microbiology, Vol. 35, No. 10, 1997, pp. 26422648.

[21] A. G. Rincon and C. Pulgarin, "Bactericidal Action of Illuminated $\mathrm{TiO}_{2}$ on Pure Escherichia coli and Natural Bacteria Consortia: Post Irradiation Events in the Dark and Assessment of the Effective Disinfection Time," Applied Catalysis B: Environmental, Vol. 49, No. 2, 2004, pp. 99-112. doi:10.1016/j.apcatb.2003.11.013

[22] W. A. M. Hijnen, E. F. Beerendonk and G. J. Medema, "Inactivation Credit of UV Radiation for Viruses, Bacteria and Protozoan (oo)Cysts in Water: A Review," Water Research, Vol. 40, No. 1, 2006, pp. 3-22. doi:10.1016/j.watres.2005.10.030

[23] R. B. Kapuscinski and R. Mitchell, "Solar Irradiation Induces Sublethal Injury in Escherichia coli in Seawater," Applied and Environmental Microbiology, Vol. 41, No. 3, 1981, pp. 670-674.

[24] J. A. Imlay, "Cellular Defenses against Superoxide and Hydrogen Peroxide," Annual Review of Biochemistry, Vol. 77, No. 1, 2008, pp. 755-776. doi:10.1146/annurev.biochem.77.061606.161055

[25] H. Gallard, J. De Laat and B. Legube, "Spectrophotometric Study of the Formation of Iron(III)-Hydroperoxy Complexes in Homogeneous Aqueous Solutions," Water Research, Vol. 33, No. 13, 1999, pp. 2929-2936. doi:10.1016/S0043-1354(99)00007-X

[26] J. D. Oliver, "Recent Findings of on the Viable but Non Culturable State in Pathogenic Bacteria," FEMS Microbiology Reviews, Vol. 34, No. 4, 2010, pp. 415-425.
[27] L. Fang, P. Cai, W. Chen, W. Liang, Z. Hong and Q. Huang, "Impact of Cell Wall Structure on the Behaviour of Bacterial Cells in the Binding of Cooper and Cadmium," Colloid Surface A, Vol. 347, No. 1, 2009, pp. 50-55. doi:10.1016/j.colsurfa.2008.11.041

[28] Z. Cheng and Y. Li, "What Is Responsible for the Initiating Chemistry of Iron-Mediated Lipid Peroxidation: An update," Chemical Reviews, Vol. 107, No. 3, 2007, pp. 748-766. doi: $10.1021 / \mathrm{cr} 040077 \mathrm{w}$

[29] A. Chatti, N. Messaoudi, M. Mihoub and A. Landoulsi, "Effects of Hydrogen Peroxide on the Motility, Catalase and Superoxide Dismutase of Dam and/or seqA Mutant of Salmonella typhimurium," World Journal of Microbiology and Biotechnology, Vol. 28, No. 1, 2012, pp. 129133. doi:10.1007/s11274-011-0801-8

[30] M. R. Barer, R. J. Smith, R. P. Cooney and P. T. Kimmitt, "Relationships between Culturability, Activity and Virulence in Pathogenic Bacteria," Journal of Infection and Chemotherapy, Vol. 6, No. 2, 2000, pp. 108-111. doi:10.1007/PL00012148

[31] I.-S. Kong, T. C. Bates, A. Hülsmann, H. Hassan, B. E. Smith and J. D. Oliver, "Role of Catalase and oxyR in the Viable but Nonculturable State of Vibrio vulnificus," FEMS Microbiology Ecology, Vol. 50, No. 3, 2004, pp. 133-142. doi:10.1016/j.femsec.2004.06.004

[32] I. J. Sanabria, J. Wist and C. Pulgarin, "Photocatalytic Disinfection Treatments: Viability, Culturability and Metabolic Changes of $E$. coli Using Different Measurement Methods," DYNA-Colombia, Vol. 78, No. 166, 2011, pp. 150157.

[33] J. D. Oliver, M. Dagher and K. Linden, "Induction of Escherichia coli and Salmonella typhimurium into the Viable but Nonculturable State Following Chlorination of Wastewater," Journal of Water and Health, Vol. 3, No. 3, 2005, pp. 249-257. 